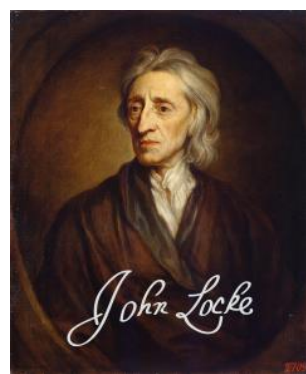

LOCKE STUDIES

Vol. 17

https://doi.org/10.5206/ls.2017.858 | ISSN: 2561-925X

Originally published: 2017

Published online: 01 JANUARY 2019

(c) Locke Studies, 2017

\title{
Recent Publications on Locke
}

JOHN ATTIG (PENNSYLVANIA STATE UNIVERSITY, RETIRED)

Recommended citation:

Attig, John. "Recent Publications on Locke." Locke Studies 17 (2017): 5-38.

https://doi.org/10.5206/ls.2017.858.

For more information about this article:

see this article's webpage.

Locke Studies is published by The John Locke Society.

This is an open access article published under the terms of the Creative Commons AttributionNonCommercial-ShareAlike 4.0 International license, which permits use, distribution and reproduction in any medium, provided the original work is properly cited and shared under the original license. 


\section{RECENT PUBLICATIONS ON LOCKE}

JOHN C. ATTIG

AFFINITO, A. 'Educare al governo di sé: Locke e il ruolo della religione nella formazione dell'uomo libero', Forum: supplement to Acta philosophica 1 (2015): 59-73. Online, accessed 7 February 2016).

http://forum-phil.pusc.it/articoli/v01-a05

*AFFINITO, A. 'John Locke, legge di natura, diritti, rivelazione', in Raffaella Santi, Costanza Ciscato, Alessio Affinito (eds.), L'alba del dio mortale: il problema della secolarizzazione nel pensiero politico del sec. XVII (Lex naturalis: storia del diritto naturale modern, 4): 301-476. Milan. (2016)

*AGUILAR, S. Locke: la mente es una tabula rasa. (Biblioteca Descubrir la filosofía, 10). [Barcelona]. (2015)

AKUVA, I. I. 'Prerogative in John Locke's Two Treatises of Government and the Tyranny of the Obasanjo Presidency in Nigeria's Nascent Democracy, 1999-2007', Africology: The Journal of Pan African Studies 9 (2016): 166-84.

ALLEGRA, A. (ed.), Perspectives on Locke: Monographica, Etica \& Politica. Ethics \& Politics 18/2 (2016): 5-239. Chapters by Lotti, Menon, Herrero, Layman, Poggi, Casson, Zanardi, Russo, and Di Biase.

*ALZATE, E. B. Religious Liberty in a Lockean Society. New York. (2017)

ANDREW, E. 'Locke on Consent, Taxation and Representation', Theoria 62 (2015): 15-32. 
ANDRONE, M. 'Notes on John Locke's Views on Education', Procedia 137 (2014): 74-79.

ANSTEY, P. R. 'The Coherence of Cohesion in the Later Leibniz', Br. J. Hist. Phil. 24 (2016): 594-613.

ANSTEY, P. R. 'Locke's Earliest Use of the Term "Experimentall Naturall Philosophy", Early Modern Experimental Philosophy [online]. Posted on September 8, 2017. Online, accessed 8 September, 2017.

https://blogs.otago.ac.nz/emx-phi/2017/09/ lockes-earliest-use-ofthe-term-experimentall-naturall-philosophy/

ANSTEY, P. R. 'Further Reflections on Locke's Medical Remains', Locke Studies 15 (2015): 215-42.

ANSTEY, P. R. 'John Locke and the Philosophy of Mind', J. Hist. Phil. 53 (2015): 221-44.

ANSTEY, P. R. 'Locke, John (1632-1704)', in The Routledge Encyclopedia of Philosophy (online). [London]. (2017)

ANSTEY, P. R. 'Locke and Natural Philosophy', in Matthew Stuart (ed.), A Companion to Locke, 64-81. Oxford. (2016)

ANSTEY, P. R. 'Locke and the Problem of Necessity in Early Modern Philosophy', in Max Cresswell, Edwin Mares, Adriane Rini (eds.), Logical Modalities from Aristotle to Carnap: The Story of Necessity, 174-93. Cambridge. (2016)

ANSTEY, P. R. 'Locke on Measurement', Studies in Hist. and Phil. of Science. Part A, 60 (2016): 70-81.

ARESHIDZE, G. 'Does Toleration Require Religious Skepticism? An Examination of Locke's Letters on Toleration and Essay Concerning Human Understanding', Interpretation: A Journal 
of Political Philosophy 43 (2016): 29-56. Repr. in idem, Democratic Religion from Locke to Obama: Faith and the Civic Life of Democracy. Lawrence, KS. (2016)

ARNESON, R. 'Liberalism and Equality', in Steven Wall (ed.), The Cambridge Companion to Liberalism, 212-36. Cambridge. (2015)

ARNESON, R. 'Locke and the Liberal Tradition', in Stuart (ed.), A Companion to Locke, 528-45.

ASHWORTH, E. J. 'Locke and Scholasticism', in Stuart (ed.), A Companion to Locke, 82-99.

*BACHOFEN, B. 'L'usage de la fiction anecdotique dans la constitution du self-made man: analyse de quelques examples', in Raphaël Chappé \& Pierre Crétois (eds.), L’homme presuppose, 45-56. Aix-en-Provence. (2014)

BALTES, J. The Empire of Habit: John Locke, Discipline, and the Origins of Liberalism. Rochester, NY. (2016)

BARR, R. A. "'Barren Desarts of Arbitrary Words": Language and Communication in Collier and Fielding's The Cry', Women's Writing 23 (2016): 87-105.

BAXTER, D. L. M. 'Hume on Substance: A Critique of Locke', in Paul Lodge and Tom Stoneham (eds.), Locke and Leibniz on Substance, 45-62. New York. (2015)

BEJAN, T. 'Locke on Toleration, (In)Civility and the Quest for Concord', Hist. Pol. Thought 37 (2016): 556-87.

BEJAN, T. Mere Civility: Disagreement and the Limits of Toleration. Cambridge, MA. (2017). ("“A Bond of Mutual Charity": Locke and the Quest for Concord', 112-43). 
BENZAQUÉN, A. 'Educational Designs: The Education and Training of Younger Sons at the Turn of the Eighteenth Century', J. Family History 40 (2015): 462-84.

BENZAQUÉN, A. "“No Greater Pleasure in This Life": The Friendship of John Locke and Edward Clarke', in Amyrose McCue Gill and Sarah Rolfe Prodan (eds.), Friendship and Sociability in Premodern Europe: Contexts, Concepts, and Expressions (Publications of the Centre for Reformation and Renaissance Studies. Essays and Studies, 33), 43-70. Toronto. (2014)

BISSET, S. 'Jean Barbeyrac's Theory of Permissive Natural Law and the Foundation of Property Rights', J. Hist. Ideas 76 (2015): 541-62.

*BJÖRKLUND, S. Det Redbara Samtalet: Locke och Popper mot Heidegger. Stockholm. (2015)

BLANK, A. 'Leibniz, Locke, and the Early Modern Controversy over Legal Maxims', Hist. Euro. Ideas 41 (2015): 1080-92.

BOEKER, R. John Locke: Identity, Persons, and Personal Identity. (Oxford Bibliographies. Philosophy). [Oxford and New York]. (2013). Online bibliography; available by subscription.

BOEKER, R. 'Locke and Hume on Personal Identity: Moral and Religious Differences', Hume Studies 41 (2015): 105-35.

BOEKER, R. 'Locke on Personal Identity: A Response to the Problems of his Predecessors', J. Hist. Phil. 55 (2017): 407-34.

BOEKER, R. 'The Moral Dimension in Locke's Account of Persons and Personal Identity', Hist. Phil. Q. 31 (2014): 229-47. 
BOEKER, R. 'The Role of Appropriation in Locke's Account of Persons and Personal Identity', Locke Studies 16 (2016): 3-39.

BOER, R, \& PETTERSON, C. Idols of Nations: Biblical Myth at the Origins of Capitalism. Minneapolis, MN. (2014) ('John Locke and the Trouble with Adam', 47-86).

BOLTON, M. B. 'Locke on Thinking Matter', in Stuart (ed.), A Companion to Locke, 334-53.

BOLTON, M. B. 'Locke's Account of Substance in Light of his General Theory of Identity', in Lodge and Stoneham (eds.), Locke and Leibniz on Substance, 63-88.

BOU-HABIB, P. 'Locke, Natural Law and Civil Peace: Reply to Tate', Euro. J. Pol. Theory 16 (2017): 122-27. [Reply to Tate 2017]

BOU-HABIB, P. 'Locke's Tracts and the Anarchy of the Religious Conscience', Euro. J. Pol. Theory 14 (2015): 3-18.

BOYD, R. 'Locke on Property and Money', in Stuart (ed.), A Companion to Locke, 394-412.

BRADY, M. 'Acting for the Public Good: Locke on Freedom and Judgment', Int. Phil. Q. 57, [no. 1, issue 225] (2017): 43-60.

BROAD, J. 'Mary Astell on Marriage and Lockean Slavery', Hist. Pol. Thought 35 (2014): 717-38.

*BRYKMAN, G, \& TRÉMOLIÈRES, F. Essai sur l'entendement humain de John Locke: les fiches de lecture. [Paris]. (2015)

*CAPALDI, N, \& LLOYD, G. Liberty and Equality in Political Economy: From Locke versus Rousseau to the Present. (New 
thinking in political economy). Cheltenham. (2016) (Ch. 1, 'John Locke and the Three Pillars of Liberty')

CAREY, D. 'John Locke, Edward Stillingfleet and the Quarrel over Consensus', Paragraph: A Journal of Modern Critical Theory 40 (2017): 61-80.

CASSON, D. 'John Locke, Clipped Coins, and the Unstable Currency of Public Reason', in Allegra (ed.), Perspectives on Locke: Monographica, Etica \& Politica. Ethics \& Politics 18/2 (2016), 153-80.

CHOTTIN, M. Le partage de l'empirisme: une histoire du problème de Molyneux aux XVII et XVIII ${ }^{e}$ siècles (Travaux de philosophie, 22). Paris. (2014). ('Locke: ancrer le jugement dans l'expérience', 100-35, and 'Locke: la vue autodidacte', 320-68).

CHUMBITA, J. S. 'La configuración del pueblo en la resistencia: un abordaje contemporáneo sobre la obra de John Locke' Revista SAAP 8 (2014): 177-205.

CHUMBITA, J. S. 'Teología política, libertad natural, paz relativa y secularización en el estado de naturaleza descrito por John Locke' ('Political Theology, Natural Liberty, Relative Peace and Secularization in John Locke's State of Nature'), Bajo palabra 2 (2014): 191-202.

CLANTON, J. C. 'John Calvin and John Locke on the Sensus Divinitatis and Innatism', Religions 8, issue 2 (2017). Online, accessed 7 January 2018

http://www.mdpi.com/2077-1444/8/2/27

CLARKE, B. 'The Wider World of Locke's Landlady, Rabsy Smithsby', Locke Studies 16 (2016): 195-213. 
CONNOLLY, P. J. 'Locke and Wilkins on Inner Sense and Volition', Locke Studies 14 (2014): 239-59.

CONNOLLY, P. J. 'Locke and the Laws of Nature', Phil. Studies 172 (2015): 2551-64.

CONNOLLY, P. J. 'Lockean Superaddition and Lockean Humility', Studies in Hist. and Phil. of Science 51 (2015): 5361.

CONTI, G. 'Lockean Toleration and the Victim's Perspective', Euro. J. of Pol. Theory 14 (2015): 76-97.

CRIGNON, C. Locke médecin: manuscrits sur l'art médical. (Textes de philosophie, 11). Paris. (2016)

DALAQUA, G. H. 'Lei natural e lei civil em John Locke' ('Natural Law and Civil Law in John Locke'), Aufklärung: Revista de Filosofia 1 (2015): 163-86.

DAVIES, P. 'Uneasiness: The Line between Sterne's Novel and Locke's Essay', Textual Practice 31 (2017): 247-64.

DAVIS, M. 'Locke's Political Society: Some Problems of Terminology in Two Treatises of Government', J. Moral Phil. 11 (2014): 209-31.

DEMPSEY, L. P. 'John Locke, "Hobbist”: Of Sleeping Souls and Thinking Matter', Can. J. Phil. 47 (2017): 454-76.

DE ROSA, R. 'Locke's Critique of Innatism', in Stuart (ed.), A Companion to Locke, 157-74.

DESAN, C. Making Money: Coin, Currency, and the Coming of Capitalism. Oxford. (2014) ('Re-theorizing Money', 330-59). 
*DI BIASE, G. 'Aristotle's Physica in John Locke's Schemes of Natural Philosophy', Rivista di filosofia neo-scolastica 107 (2015): 867-81.

DI BIASE, G. 'A Gentleman's "Moderate Knowledge": Mediocrity in John Locke's Some Thoughts Concerning Education', XVII-XVIII: Revue de la Société d'Études angloaméricaines 72 (2015): 57-80.

DI BIASE, G. 'Intolerância em Locke: luta pela coexistência pacifica' [interview by Márcia Junges and João Vitor Santos with Giuliana Di Biase], IHU Online 470 (2015). Online, accessed 29 March 2017.

http://www.ihuonline.unisinos.br/index.php?option=com_content $\underline{\text { view }=\text { article } \& \mathrm{id}=6071 \& \text { secao }}$

*DI BIASE, G. 'John Locke: la mediocrity come fondamento della dottrina sulla tolleranza', Humanitas 6 (2014): 947-59.

*DI BIASE, G. 'John Locke: verità di fede, politica, tolleranza', in Antonella Besussi (ed.), Filosofia, verità e politica: questione classiche. (Biblioteca di testi e studi. Filosofia, 1016), 47-61. Rome. (2015)

*DI BIASE, G. 'John Locke on Monotheism: A Dispute with Johannes Hudde', Archivio di filosofia 82 (2014): 317-29.

DI BIASE, G. 'John Locke's Stoicism: Grief, Apathy and Sympathy', in Allegra (ed.), Perspectives on Locke: Monographica, Etica \& Politica. Ethics \& Politics 18/2 (2016), 215-39.

DI BIASE, G. 'Liberal Education in John Locke's Some Thoughts Concerning Education', Giornale critico della filosofia italiana 11 (2015): 564-87. 
DI BIASE, G. 'Physica in John Locke's Adversaria and Classifications of the Branches of Knowledge', Locke Studies 16 (2016): 69-166.

DI BIASE, G. 'Theologia, Ethics, and Natural Law in Locke's Classifications of Knowledge and Adversaria', Locke Studies 14 (2014): 177-237.

DOWNING, L. 'Locke and Descartes', in Stuart (ed.), A Companion to Locke, 100-119.

DOWNING, L. 'Locke's Choice between Materialism and Dualism', in Lodge and Stoneham (eds.), Locke and Leibniz on Substance, 128-45.

DOWNING, L. 'Locke's Metaphysics and Newtonian Metaphysics', in Zvi Biener and Eric Schliesser (ed.), Newton and Empiricism, 97-118. Oxford. (2014)

DRAPER, K. War and Individual Rights: The Foundations of Just War Theory. New York. (2016) ('A Lockean Framework of Rights', 18-36)

ENG, D. T. C. 'Hobbes and Locke Revisited: on Understanding, Nature and the Sovereign in the 21st Century', Agathos 6 (2015): 98-107.

*ENGELHARD, F. 'Die Prërogative in John Lockes System geteilter Gewalten' [Prerogative in John Locke's System of Separated Powers], Zeitschrift für Politik 62 (2015): 243-62.

ENGLERT, G. 'Liberty and Industry: John Locke, John Stuart Mill, and the Economic Foundations of Political Membership', Polity 48 (2016), 551-79.

*ETIEYIBO, E. 'Substancehood in Locke, Spinoza, and Kant', 
Philosophia: Int. J. of Phil. 18 (2017): 43-59.

FABRI, E. 'De l'appropriation à la propriété: John Locke et la fécondité d'un malentendu devenu classique', Philosophiques 43 (2016): 343-69.

*FAUVERGUE, C. Les Lumières et Leibniz: avant la publication des Nouveaux essais sur l'entendement humain. (Les dixhuitièmes siècles, 175). Paris. (2015)

FOWLER, J. "“Procedes huc": Voltaire, Newton, and Locke in Lettres philosophiques', Neophilologus 101 (2017): 15-28.

FRECKNALL-HUGHES, J. 'Locke, Hume, Johnson and the Continuing Relevance of Tax History', eJournal of Tax Research 12 (2014): 87-103.

*GAMARRA QUINTANILLA, G. Locke; el Estado debe proteger los derechos y libertades individuales de los ciudadanos. (Aprender a pensar). [Barcelona]. (2016)

GARRETT, D. 'Liberty and Suspension in Locke's Theory of the Will', in Stuart (ed.), A Companion to Locke, 260-78.

GARRETT, J. 'The Johns Agree: Rawls, Finnis, and Locke on Open Immigration from Mexico to the United States', Faulkner Law Review 7 (2015/16): 129-53.

GIUNTINI, C. Presenti a se stessi: la centralità della coscienza in Locke. (Giornale critic della filosofia italiana. Quaderni, 31). Florence. (2015)

GLASGOW, D. 'Political Theory Simulations in the Classroom: Simulating John Locke's Second Treatise of Government', PS, Political Science and Politics 48 (2015): 368-72. 
GOLDIE, M. 'Locke and America', in Stuart (ed.), A Companion to Locke, 546-63.

GOLDIE, M. 'Locke's Life', in Stuart (ed.), A Companion to Locke, 27-44.

GOLLAPUDI, A. 'Personhood, Property Rights, and the Child in John Locke's Two Treatises of Government and Daniel Defoe's Fiction', Eighteenth-century Fiction 28 (2015/16): 25-58.

GORDON-ROTH, J. 'Catharine Trotter Cockburn's Defence of Locke', The Monist 98 (2015): 64-76.

GORDON-ROTH, J. 'Locke on the Ontology of Persons', Southern J. of Phil. 53 (2015): 97-123.

GORDON-ROTH, J. 'Locke's Place-Time-Kind Principle', Phil. Compass 10 (2015): 264-74.

GORHAM, G, \& SLOWIK, E. 'Locke and Newton on Space and Time and their Sensible Measure', in Biener and Schliesser (eds.), Newton and Empiricism, 119-37.

GRANT, R. W, \& HERTZBERG, B. 'Locke on Education', in Stuart (ed.), A Companion to Locke, 448-65.

*GRÉGOIRE, V. Théories de l'État et problèmes coloniaux (XVIe-XVIIIe siècle): Vitoria, Bacon, Hobbes, Locke, Rousseau. (Les dix-huitièmes siècles, 194). Paris. (2017)

HACKER, P. M. S. 'An Intellectual Entertainment: Thought and Thinking', Phil. 92 (2017): 97-128.

HARRIS, I. 'Some Reflections on Critical-Text Editing: The Case of Hobbes's Leviathan', Locke Studies 16 (2016): 215-71. 
*HENRICH, N. Das Emissionsrecht als Sachenrecht: Begründung, Erwerb, Inhalt und Grenzen in rechtsphilosophischer Auseinandersetzung mit den Privatrechtskonzeption John Lockes und Immanuel Kants. (Schriftenreihe Schriften zur Rechts- und Staatsphilosophie, Band 17). Hamburg. (2015)

HERRERO, M. 'The "Philosophical Bible" and the Secular State', The European Legacy 22 (2017): 31-48.

*HERRERO, M. La política revolucionaria de John Locke. (Biblioteca de historia y pensamiento político). Madrid. (2015)

HERRERO, M. 'The Quest for Locke's Political Theology', in Allegra (ed.), Perspectives on Locke: Monographica, Etica \& Politica. Ethics \& Politics 18/2 (2016), 83-109.

HILL, B. 'Academic Scepticism and the Early Royal Society', in Plínio Junqueira Smith and Sébastien Charles (eds.), Academic Scepticism in the Development of Early Modern Philosophy. (International archives of the history of ideas=Archives internationales d'histoire des idées, 221), 103-24. Heidelberg. (2017)

*HOERL, C. 'On the View That We Cannot Perceive Movement and Change: Lessons from Locke and Reid', J. of Consciousness Studies 24 (2017): 88-102.

HOFF, S. 'Locke and the Nature of Political Authority', Rev. of Politics 77 (2015): 1-22.

HOLT, M. P. 'Belief and its Limits', in Hamish Scott (ed.), The Oxford Handbook of Early Modern European History, 13501750. Volume I, Peoples and Places, 720-44. Oxford. (2015)

HUDSON, N. 'Challenging the Historical Paradigm: Tories, 
Whigs, and Economic Writing, 1680-1714', Eighteenth-century Life 40 (2016): 68-88.

HUNT, B. A., JR. 'Locke on Equality', Pol. Research Q. 9 (2016): 546-56.

*INOGUCHI, T, \& LE, T. Q. L. 'Toward Modelling a Global Social Contract: Jean-Jacques Rousseau and John Locke', Japanese J. of Pol. Science 17 (2016), 489-522.

JACOVIDES, M. 'Locke on Perception', in Stuart (ed.), A Companion to Locke, 175-92.

JACOVIDES, M. Locke's Image of the World. Oxford. (2017)

*JANECZEK, S. 'Kultura języka a kultura logiczna w myśli Johna Locke'a', Roczniki filozoficzne 62, nr 2 (2014), 5-26.

JAWORSKI, P. M., \& SHOEMAKER, D. 'Me and Mine', Phil. Studies 175 (2018): 1-22.

JOLLEY, N. Locke's Touchy Subjects: Materialism and Immortality. Oxford. (2015). ISBN 978-0-19-873709-4.

JOLLEY, N. Toleration and Understanding in Locke. Oxford. (2016). ISBN 978-0-19-879170-6.

JONES, J-E. 'Lockean Real Essences and Ontology', Southwest Phil. Rev. 32 (2016): 137-62.

*KASHALA KAVULA, F. Propos sur le libéralisme politique et religieux: dialogue idéal entre John Locke et Baruch Spinoza. Paris. (2014)

KAUFMAN, D. 'Locke's Theory of Identity', in Stuart (ed.), A Companion to Locke, 236-59. 
KEISER, J. 'What's the matter with madness? John Locke, the Association of Ideas, and the Physiology of Thought', in Chris Mounsey (ed.), The Idea of Disability in the Eighteenth Century, 49-70. Lewisburg, PA. (2014)

KELLY, P. 'Armitage on Locke on International Theory: The Two Treatises of Government and the Right of Intervention', Hist. Euro. Ideas 41 (2015): 49-61.

KIM, H-K. 'Lockean Humility', Phil. 89 (2014): 537-58.

KIM, H-K. 'The Supposed but Unknown: A Functionalist Account of Locke's Substratum', in Lodge \& Stoneham (eds.), Locke and Leibniz on Substance, 28-44.

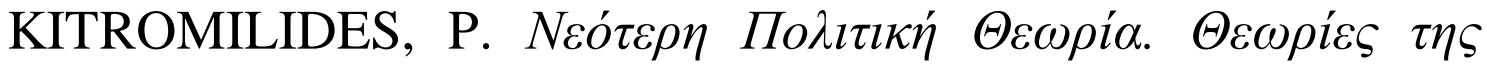
$\varepsilon \lambda \varepsilon v \theta \varepsilon \rho i \alpha s$. [Modern Political Theory. Theories of Liberty]. Sixth edition. Athens. (2016), esp. part 1.

*KLEISOARY, J, with JACKSON, I. An Analysis of John Locke's Two Treatises of Government. London. (2017)

KOGANZON, R. "“Contesting the Empire of Habit": Habituation and Liberty in Lockean Education', Am. Pol. Sci. Rev. 110 (2016): 547-58.

*KOJŌ, T. ロック倫理学の再生. 京都: 晃洋書房, 2017. [Rokku rinrigaku no saisei]. Kyōto. (2017)

LÄHTEENMÄKI, V. 'L'attention dans la philosophie de l'esprit de John Locke', in L'attention au XVIIe siècle: conceptions et usages, 73-86. Paris. (2017)

LASCANO, M. P. 'Locke's Philosophy of Religion', in Stuart (ed.), A Companion to Locke, 469-85. 
LASELVA, S. V. 'Toleration without Hate Speech: The Keegstra Decision, American Free Speech Exceptionalism and Locke's Letter', Can. J. Pol. Sci. 48 (2015): 699-718.

LAYMAN, D. M. 'The Quest for Locke's Political Theology', in Allegra (ed.), Perspectives on Locke: Monographica, Etica \& Politica. Ethics \& Politics 18/2 (2016), 111-32.

LE BLANC, H. 'Figures du signe à l'âge classique: Port-RoyalHobbes-Locke', Methodos 16 (2016). Online, accessed 4 October 2017.

http://journals.openedition.org/methodos/4515

*LEFÈVRE, B. John Locke, un philosophe en avance sur son temps: de la tolérance religieuse au libéralisme. (Grandes personalités, numéro 29). Brussels. (2015).

LEISINGER, M. A. 'Locke's Arguments against the Freedom to Will', Br. J. Hist. Phil. 25 (2017): 642-62.

LENZ, M. 'Locke contre Leibniz à propos du langage: deux sortes d'externalisme?' ('Locke vs. Leibniz on Language: Two Kinds of Externalism?'), Methodos 14 (2014). Online, accessed 4 October 2017.

http://journals.openedition.org/methodos/4044

LIND, M. 'Lockepolitik', National Interest 143 (2016): 63-72.

*LIS, R. 'Jean Bodin, John Locke i Jean Jacques Rousseau: o paradoksie suwerenności i ludowładztwa oraz próbach jego rozwiązania', Studia Polityczne 2 (2014): 69-83.

LISMAN, J. E. 'Locke's View of the Hard Problem of Consciousness and its Implications for Neuroscience and Computer Science', Frontiers of Psychology 8 (2017): 1-3. 
*LOCKE, J. Carta sobre la tolerancia (1689) [and] Extractos de la Tercera carta para la tolerancia (1692) [Spanish translation, tr. Emilio Martínez Navarro]. (Los esenciales de la filosofía). Madrid. (2017)

*LOCKE, J. Del abuso de las palabras [tr. Martin Schifino]. (Great ideas). [Madrid]. (2014)

*LOCKE, J. Dos tractos sobre el govierno y otros escritos [Spanish translation, tr. Daniel Mielgo Bregazzi. (Clásicos del pensamiento, 68). Madrid. (2015)

LOCKE, J. The Enhanced Edition of John Locke's Two Treatises of Civil Government (1689, 1764). (Classics of Liberty: The Enhanced Edition). Indianapolis, IN. (2014). Online, accessed 8 June 2017: http://oll.libertyfund.org/titles/2638

*LOCKE, J. Ensaio sobre o entendimento humano, [Portuguese translation, tr. Eduardo Abranches de Soveral, rev. Gualter Cunha, Ana Luísa Amaral]. 5 ${ }^{\mathrm{a}}$ edición. (Textos clássicos). Lisbon. (2014)

*LOCKE, J. An Essay Concerning Human Understanding with the Second Treatise of Government, introduction by Mark G. Spencer. (Wordsworth Classics of World Literature). Ware, Herts. (2014)

*LOCKE, J. Politisches Denken [ed. Klaus Kremb]. Wiesbaden. (2015)

*LOCKE, J. La razonabilidad del cristianismo tal como es presentado en las Escrituras [Spanish translation, tr. Leonardo Rodríguez Duplá, Leopoldo José Prieto López]. (Clásicos del pensamiento, 148). Madrid. (2017) 
*LOCKE, J, The Second Treatise of Civil Government [ed. Andrew Bailey]. Peterborough, Ontario. (2015)

*LOCKE, J. Second Treatise of Government and A Letter concerning Toleration, ed. Mark Goldie. Oxford. 2016.

*LOCKE, J. Tanker om opdragelsen, [Danish translation of Some Thoughts Concerning Education, tr. Morten G. Larsen, ed. Lone Dalgaard and Joachim Wang, introduction by Mogens Chrom Jacobsen. (Kulturklassiker Klim). Aarhus. (2016)

*LOCKE, J. Traité du gouvernement civil: traduction de David Mazel (1795) [and] Lettre sur la tolérance: traduction de Jean LeClerc (1710). (Philosophies vivantes, 28). Anjou, Québec. (2014)

*LOCKE, J. Two Treatises of Government [ed. Lee Ward]. (Focus Philosophical Library). Indianapolis, IN. (2016).

LODGE, P, \& STONEHAM, T. (eds.). Locke and Leibniz on Substance. (Routledge Studies in Seventeenth-Century Philosophy, 14). New York and London. (2015). Chapters by Millican, Kim, Baxter, Bolton, Newman, Rickless, and Downing.

LOEB, L. E. 'Locke and British Empiricism', in Stuart (ed.), A Companion to Locke, 505-27.

LOLORDO, A. 'Locke on Knowledge and Belief', in Stuart (ed.), A Companion to Locke, 296-312.

LONGAKER, M. 'John Locke's Practice of Argumentation', Informal Logic 34 (2014), 364-92.

LONGAKER, M. Rhetorical Style and Bourgeois Virtue: Capitalism and Civil Society in the British Enlightenment. (The 
RSA Series in Transdisciplinary Rhetoric). University Park, PA. (2015), ('Locke on Clarity', 12-42).

*LORD, J. John Locke and Two Treatises of Government. (The Words That Inspired the Founding Fathers). New York. (2017)

LOTTI, B. 'La legge di natura in Locke: una questione teologicopolitica', in Allegra (ed.), Perspectives on Locke: Monographica, Etica \& Politica. Ethics \& Politics 18/2 (2016), $13-58$.

LOVE, W. 'Monarchical Sovereignty and Christology in John Locke's Two Treatises of Government and The Reasonableness of Christianity', J. of Scriptural Reasoning 15, no. 1 (March 2016). Online, accessed 29 June 2016. https://jsr.shanti.virginia.edu/back-issues/volume-15-no-1march-2016-public-scripture/monarchical-sovereignty-andchristology-in-john-lockes-two-treatises-of-government-andthe-reasonable-ness-of-christianity/

LOWE, E. J. 'Language and Meaning', in Stuart (ed.), A Companion to Locke, 279-95.

MARKO, J. S. 'Justification, Ecumenism, and Heretical Red Herrings in John Locke's The Reasonableness of Christianity', Phil. \& Theology 26 (2014): 245-66.

MARKO, J. S. Measuring the Distance between Locke and Toland: Reason, Revelation, and Rejection during the LockeStillingfleet Debate. Eugene, OR. (2017)

MARKO, J. S. 'The Promulgation of Right Morals: John Locke on the Church and the Christian as the Salvation of Society', J. of Markets \& Morality 19 (2016): 41-59.

MARKO, J. S. 'Why Locke's "Of Power" is Not a Metaphysical 
Pronouncement: Locke's Response to Molyneux's Critique', Phil. \& Theology 29 (2017): 41-68.

MARSHALL, C. 'Lockean Empathy', Southern J. of Phil. 54 (2016): 87-106.

MARTINS, A. E. M. 'John Locke e a liberdade como fundamento da propriedade’, Griot 11, n. 1 (julio 2015), 315-23.

MARUŠIĆ, J. S. 'Locke's Simple Account of Sensitive Knowledge', Phil. Rev. 125 (2016): 205-39.

MATAR, N. 'England and Religious Plurality: Henry Stubbe, John Locke and Islam', in Charlotte Methuen, Andrew Spicer, and John Wolffe (eds.), Christianity and Religious Plurality. (Studies in Church History, 51), 181-203. Woodbridge, Suffolk and Rochester, NY. (2015)

MENON, M. 'Leo Strauss e il problema teologico-politico di John Locke', in Allegra (ed.), Perspectives on Locke: Monographica, Etica \& Politica. Ethics \& Politics 18/2 (2016), 59-82.

MEYERS, D. T. 'Recovering the Human in Human Rights', Law, Culture and the Humanities 12 (2016): 474-84.

MILLICAN, P. 'Locke on Substance and Our Ideas of Substances', in Lodge and Stoneham (eds.), Locke and Leibniz on Substance, $8-27$.

MILTON, J. R. 'The Genesis and Composition of the Essay', in Stuart (ed.), A Companion to Locke, 123-39.

MILTON, J. R. 'Locke and the Perils of Anecdotal History', Eighteenth-Century Thought 5 (2014): 147-77.

MILTON, J. R. 'Some Possible Corruptions in the Text of Locke's 
Essay', Locke Studies 14 (2014): 17-28.

MOORE, T. 'Locke on the Origins of Language', Think 16 [issue 46] (2017): 67-78.

MOORE, T. 'Locke's Error?', Think 14 [issue 39] (March 2015), 77-85.

*MOORE, T. Understanding Misunderstanding: Locke Holds the Key. Ely. (2016)

*MUNDÓ, J. 'Political Freedom in Locke's Republicanism', in Yannick Bosc, et al. (eds.), Cultures des républicanismes: pratiques-représentations-concepts de la Révolution anglaise à aujourd'hui, 103-16. Paris. (2015)

*NACOL, E. An Age of Risk: Politics and Economy in Early Modern Britain. Princeton, NJ. (2016)

NADLER, S, \& NADLER, B. Heretics! The Wondrous (and Dangerous) Beginnings of Modern Philosophy. Princeton, NJ. (2017). ('London 1689', 121-59).

NAGEL, J. 'Sensitive Knowledge: Locke on Skepticism and Sensation', in Stuart (ed.), A Companion to Locke, 313-33.

NAZAR, H. 'Locke, Education, and "Disciplinary Liberalism"', Rev. of Pol. 79 (2017): 215-38.

NEWMAN, L. 'Locke on Substance, Consciousness, and Personal Identity', in Lodge and Stoneham (eds.), Locke and Leibniz on Substance, 89-109.

NEWTON, J. 'Locke's Skepticism of Ordinary Language', Hist. Phil. Q. 34 (2017): 1-15. 
NEWTON, J. 'Locke on the "Species" of Substances', Locke Studies 14 (2014): 105-20.

NIMBALKAR, N. 'Corrections to my Paper, John Locke on Personal Identity', Mens Sana Monographs 12 (2014), 168-69. [Corrections to Nimbalkar 2011]

*NOLL, A. J. John Locke und das Eigentum: eine Einführung in den Second Treatises of Government und seine 'Great Foundation of Property'. (Kritik \& Utopie). Vienna. (2016)

NORTHOVER, A. D. "Enough and as Good" in the Intellectual Commons: A Lockean Theory of Copyright and the Merger Doctrine', Emory Law Journal 65 (2016): 1363-1410.

NUMAO, J. K. 'Locke's Some Thoughts Concerning Education (1693): Fathers and Conversational Friendship', in Cesare Cuttica and Gaby Mahlberg (eds.), Patriarchal Moments: Reading Patriarchal Texts. (Textual Moments in the History of Political Thought), 81-87. London and New York. (2016)

NUOVO, V. John Locke. The Philosopher as Christian Virtuoso. Oxford. 2017.

NUOVO, V. 'The Reasonableness of Christianity and $A$ Paraphrase and Notes on the Epistles of St Paul', in Stuart (ed.), A Companion to Locke, 486-502.

OTT, W. 'Locke and the Real Problem of Causation', Locke Studies 15 (2015): 53-77.

OWEN, J. J. Making Religion Safe for Democracy: Transformation from Hobbes to Tocqueville. New York. (2015). ('Locke and the Political Theology of Toleration', 57-112)

PAGE, J. M. 'Many Men Are Good Judges in Their Own Case: 
Restorative Justice and the Nemo Iudex Principle in AngloAmerican Law', Raisons Politiques 59 (2015): 91-107.

*PEMBERTON, S. Locke's Political Thought and the Oceans: Pirates, Slaves, and Sailors. Lanham, MD. (2017)

POGGI, D. "For 'tis truth alone I seek, and that will always be welcome to me, when or from whencesoever it comes": ricerca della verità ed etica della communicazione in John Locke', in Allegra (ed.), Perspectives on Locke: Monographica, Etica \& Politica. Ethics \& Politics 18/2 (2016), 133-52.

PRISELAC, M. Locke's Science of Knowledge. (Routledge Studies in Seventeenth-Century Philosophy). London and New York. (2017)

RAATZ, G. 'Religion als Aufklärung: Anmerkungen zum Religions- und Christentumsverständnis John Lockes (16321704)', Neue Zeitschrift für Systematische Theologie und Religionsphilosophie 58 (2016), 309-24.

*RĂȚULEA, G. Dreptatea ca libertate: Locke şi problema dreptului natural. (Academica, 258). Iaşi. (2015)

RǍȚULEA, G. 'Justice et tolérance: la question du hobbisme du jeune Locke' ('Justice and Tolerance: The Problem of Hobbism in Early Locke'), Meta: Research in Hermeneutics, Phenomenology, and Practical Philosophy 7 (2015): 166-86.

REID, JASPER. 'The Common Consent Argument from Herbert to Hume', J. Hist. Phil. 53 (2015): 401-33.

*REID, JENNIFER. Inconvenient Neighbours: John Locke, Indian Law, and Gender Discrimination in Canada. Aurora, CO. (2017) 
*RENAULT, M. L'Amérique de John Locke: l'expansion coloniale de la philosophie européenne. Paris. (2014)

RICKLESS, S. 'Are Locke's Persons Modes or Substances?', in Lodge and Stoneham (eds.), Locke and Leibniz on Substance, $110-27$.

RICKLESS, S. 'Degrees of Certainty and Sensitive Knowledge: A Reply to Soles', Locke Studies 15 (2015): 99-109. [Reply to Soles 2014]

RICKLESS, S. 'Locke on Freedom', in Edward N. Zalta (ed.), Stanford Encyclopedia of Philosophy winter 2015. Online, accessed 22 February 2017.

http://plato.stanford.edu/archives/win2015/entries/locke-freedom/

RIST, J. M. Augustine Deformed: Love, Sin and Freedom in the Western Moral Tradition. New York. (2014). ('Naturalism Revised', 209-27).

ROCKWOOD, N. 'Locke on Knowledge of Existence', Locke Studies 16 (2016): 41-68.

*RODILlA, M. Á. Contrato social: de Hobbes a Rawls. Salamanca. (2014)

ROECKLEIN, R. Locke, Hume, and the Treacherous Logos of Atomism: The Eclipse of Democratic Values in the Early Modern Period. Lanham, MD. (2015). ('John Locke's Philosophy of Mind', 83-120 and 'Locke on Consent, Morals, and Education', 121-52).

ROSE, J. 'The Contexts of Locke's Political Thought', in Stuart (ed.), A Companion to Locke, 45-63.

ROSE, J. 'The Debate over Authority: Adiaphora, the Civil 
Magistrate, and the Settlement of Religion', in N. H. Keeble (ed.), 'Settling the Peace of the Church': 1662 Revisited, 29-56. Oxford. (2014)

ROSSITER, E. 'Hedonism and Natural Law in Locke's Moral Philosophy', J. Hist. Phil. 54 (2016): 203-25.

RUSSO, R. 'An Herculean Mind: il problematico ruolo di Locke come precursore dell'utilitarismo', in Allegra (ed.), Perspectives on Locke: Monographica, Etica \& Politica. Ethics \& Politics 18/2 (2016), 197-214.

ŞAHINN, K. 'John Locke'un toplum ve devlet analyişi' ('John Locke's Thought of Society and State'), Üçüncü sektör sosyal ekonomi. Third Sector Social Economic Review 52 (2017), 4155. In Turkish, with an English abstract.

SAKAL, V. 'Two Conceptions of Religious Self in Lockean Religiosity', J. of Religion 96 (2016): 332-45.

SANTOS, A. C. DOS. 'Os elementos republicanos na tolerância de John Locke’, Kriterion 130 (2014): 499-513.

*SCHNEIDER, H. Liberalismus und Religion: die Rolle der Religion in den Staatsphilosophien von Locke, Kant und Smith. Saarbrücken. (2014)

SCHULER, J. 'Empiricism without the Dogmas: Hegel's Critique of Locke's Simple Ideas', Hist. Phil. Q. 31 (2014): 347-68.

SEAGRAVE, S. A. 'Locke on the Law of Nature and Natural Rights', in Stuart (ed.), A Companion to Locke, 373-93.

SEGOVIA, J. F. 'John Locke y la ley de la moda: de la teología a la sociología de la ley natural' ('John Locke and the Law of Fashion: from Theology to Sociology of the Natural Law'), 
Revista de estudios histórico-jurídicos 36 (2014): 467-79.

*SEGOVIA, J. F. La ley natural en la telaraña de la razón: ética, derecho y política en John Locke. Madrid. (2014)

SHANKS, T. Authority Figures: Rhetoric and Imagination in John Locke's Political Thought. University Park, PA. (2014)

SHANKS, T. 'Toleration and Democratic Membership: John Locke and Michel de Montaigne on Monsters', Political Theory 43 (2015): 451-72.

SHEPPARD, K. Anti-Atheism in Early Modern England 16801720: The Atheist Answered and his Error Confuted. (Studies in the History of Christian Traditions, volume 176). Leiden. (2015) 125-136 ('Saint Epicurus?', 125-36, and 'John Locke: “Seeking Truth, and Not Triumph", 257-70).

SHERIDAN, P. 'Locke's Latitudinarian Sympathies: An Exploration of Sentiment in Locke's Moral Theory', Locke Studies 15 (2015): 131-62.

SILVA, I. 'O liberalismo como doutrina do público e do privado: Locke, Mill e Rawls' ('Liberalism as a Doctrine of Public and Private: Locke, Mill and Rawls'), Revista opinião filosófica 7 (2016), 241-57. In Portuguese, with an English abstract.

SIMENDIC, M. 'Locke's Person Is a Relation', Locke Studies 15 (2015): 79-97.

SIMMONS, A. J. 'Locke on the Social Contract', in Stuart (ed.), A Companion to Locke, 413-32.

SIMONUTTI, L. 'Locke traducteur de Nicole: Of the Weaknesse of Man', in Charles Le Blanc and Luisa Simonutti (eds.), Le masque de l'écriture: philosophie et truduction de la 
Renaissance aux Lumières, 627-39. Geneva. (2015)

SINA, M. 'Spazio e luogo in Locke e Berkeley', in Delfina Giovannozzi e Marco Veneziani (eds.), Locus-Spatium: XIV Colloquio internazionale, Roma, 3-5 gennaio 2013. (Lessico intellettuale europeo, 122), 467-505. Florence. (2014). Repr. in Sina 2015 (below).

SINA, M. Studi su John Locke: e su altri pensatori cristiani agli albrori del secolo dei lumi. (Filosofia. Richerche). Milan. (2015)

SKIDMORE-HESS, D \& SKIDMORE-HESS, C. “"Have we not an equal interest with the men of this nation?" Gender, Equality, and Genesis in John Locke's Political Thought', Int. Soc. Sci. Rev. 92 (2016), issue 1, article 2.

SMITH, B. 'Friends in the State of Nature: John Locke and the Formation of Security Communities', Polity 49 (2017): 379407.

*SMITH, B. 'On Revolution: Arendt, Locke and Republican Revisionism', Hist. Pol. Thought 36 (2015): 560-79.

SMITH, C. W. Empiricist Devotions: Science, Religion, and Poetry in Early Eighteenth-Century England. Charlottesville, VA. (2016) ('Economists Turn to Nature', 108-25, 'Locke and Defoe', 155-66, and 'Empiricist Methodologies, Empiricist Selves', 166-72).

SOLES, D. 'Certainty and Sensitive Knowledge', Locke Studies 14 (2014): 159-76.

SOLES, D. 'On Certainty and Sensitive Knowledge: A Response to Rickless', Locke Studies 15 (2015): 111-30. [Reply to Rickless 2015 (above)]. 
SOLES, D. 'The Theory of Ideas', in Stuart (ed.), A Companion to Locke, 140-56.

SOPUCK, F. 'Locke's Challenge: On Why the Success of the Acquaintance Interpretation of Reid Is Important', Hist. Phil. Q. 34 (2017): 57-77.

SOULARD, D. 'The Christ's Copy of John Locke's Two Treatises of Government', Hist. J. 58 (2015): 25-49.

STANTON, T. 'Natural Law, Judgement and Toleration in Locke', Euro. J. Pol. Theory 16 (2017): 128-35. [Reply to Tate 2017]

STANYON, M. 'Sublime Rauschen: Enlightening Sound from Locke to Klopstock', Modern Philology 114 (2017): 845-71.

*STEPKOWSKI, A. 'Umowa społeczna Locke'a: spojrzenie z perspektywy prawnej', Studia Prawno-Ekonomiczne 91 (2014), 153-63.

STOLBERG, M. 'John Locke's "New Method of Making Common-Place-Books": Tradition, Innovation and Epistemic Effects', Early Science and Medicine 19 (2014): 448-70.

STOLBERG, M. 'Medical Note-Taking in the Sixteenth and Seventeenth Centuries', in Alberto Cevolini (ed.), Forgetting Machines: Knowledge Management Evolution in Early Modern Europe. (Library of the written word, volume 53), 243-64. Leiden. (2016)

STRAWSON, G. "“The Secrets of All Hearts": Locke on Personal Identity', Royal Institute of Philosophy Supplement 76 (2015): $111-41$.

STUART, M. (ed.). A Companion to Locke. (Blackwell 
Companions to Philosophy, 59). Oxford. (2016) Essays by Stuart, Goldie, Rose, Anstey, Ashworth, Downing, Milton, Soles, De Rosa, Jacovides, Wilson, Winkler, Kaufman, Garrett, Lowe, LoLordo, Nagel, Bolton, Seagrave, Boyd, Simmons, Tuckness, Grant \& Hertzberg, Lascano, Nuovo, Loeb, and Arneson.

STUART, M. 'The Correspondence with Stillingfleet', in Stuart (ed.), A Companion to Locke, 354-69.

STUART, M. 'Introduction', in Stuart (ed.), A Companion to Locke, 1-23.

STUART, M. 'Locke on Attention', Brit. J. Hist. Phil. 25 (2017): 487-505.

STUART-BUTTLE, T. 'Shaftesbury Reconsidered: Stoic Ethics and the Unreasonableness of Christianity', Locke Studies 15 (2015): 163-213.

STUART-BUTTLE, T. "“A Burthen too heavy for humane Sufferance": Locke on Reputation', Hist. Pol. Thought 38 (2017): 644-80.

*SULMASY, D. P. 'Tolerance, Professional Judgment, and the Discretionary Space of a Physician', Cambridge $Q$. of Healthcare Ethics 26 (2017): 17-30.

*SZWED, A. 'Johna Locke'a koncepcja tolerancji jako reakcja na zasadę "cuius regio, eius religion", Roczniki filozoficzne 62 (2014): 65-85.

TABB, K. 'Madness as Method: on Locke's Thought Experiments about Personal Identity', Brit. J. Hist. Phil. Advance publication, 10 August 2017. 
TAKAI，K. 「ジョン・ロックのサミュエル・パーカー批判 」, 経済論叢 / 'Jon Rokku no Samyueru Pākā hihan', Keisai Ronsō 188 (2014)

*TAKAI, K. 国家・教会・個人: ジョン・ロックの世俗社会 認識論. (プリミエ・コレクション,73). 京都. / Kokka kyōkai kojin: Jon Rokku no sezoku shakai ninshikiron. (Purimie korekushon, 73). Kyōto. (2016)

TATE, J. W. Liberty, Toleration and Equality: John Locke, Jonas Proast and the Letters Concerning Toleration. (Routledge Studies in Social and Political Thought, 111). New York. 2016.

TATE, J. W. 'Locke, Toleration and Natural Law: A Reassessment', Euro. J. Pol. Theory 16 (2017), 109-21. [Reply to Bou-Habib 2015 and various articles by Stanton]

TATE, J. W. 'Toleration, Skepticism, and Blasphemy: John Locke, Jonas Proast, and Charlie Hebdo', Am. J. Pol. Sci. 60 (2016): 664-75.

THOMAS, E. 'Catharine Cockburn on Unthinking Immaterial Substance: Souls, Space, and Related Matters', Phil. Compass 10 (2015): 255-63.

THOMAS, E. 'On the "Evolution" of Locke's Space and Time Metaphysics', Hist. Phil. Q. 33 (2016): 305-25.

TOKARZEWSKA, M. 'Archimedean Points in a Network of Cosmological Metaphors: Fontenelle, Locke, Fichte, and Kant', SubStance 43, no. 3 [issue 135] (2014), 27-45.

*TOKARZEWSKA, M. Rettung vor Bodenlosigkeit: Neues Anfangsdenken und kosmologische Metaphern bei Locke, Leibniz, Kant, Fichte, Novalis und Jean Paul. (Warschauer 
Studien zur Kultur- und Literaturwissenschaft, Bd. 7). Frankfurt. (2015). ('Bodenlosigkeit und Anfangsdenken: von Welschildkröten, archimedischen Punkten und Gravitationskräften: Locke, Leibniz und andere in Konfrontation mit dem neuen Weltbild', 45-113')

TOMIDA, Y. 'Experiential Objects and Things Themselves: Locke's Naturalistic, Holistic Logic, Reconsidered', Locke Studies 14 (2014): 85-102.

TUCKNESS, A. 'Locke on Toleration', in Stuart (ed.), A Companion to Locke, 433-47.

TURRI, J, \& BUCKWALTER, W. 'Descartes's Schism, Locke's Reunion: Completing the Pragmatic Turn in Epistemology', Am. Phil. Q. 54 (2017), 25-45.

UDI, J. 'El derecho a la caridad: repercusiones de la teología cristiana en la teoríe de la propiedad de John Locke', Revista de filosofía 70 (2014), 149-160.

UDI, J. 'Locke and the Fundamental Right to Preservation: on the Convergence of Charity and Property Rights', Rev. of Pol. 77 (2015), 191-215.

UEHLEIN, F. A. 'Whichcote, Shaftesbury and Locke: Shaftesbury's Critique of Locke's Epistemology and Moral Philosophy', Brit. J. Hist. Phil. 25 (2017): 1031-48.

UNGER, P. Empty Ideas: A Critique of Analytic Philosophy. New York. (2014) ('Locke's Proposed Persons', 190-92, 'Locke's Lame Legacy', 192-97, and 'Beyond Locke, But Not Beyond Philosophical Thoughts Both Incorrect and Empty’, 197-201)

VAN DER VOSSEN, B. 'Locke on Territorial Rights', Pol. Studies 63 (2015): 713-28. 
VARDEN, H. 'John Locke: Libertarian Anarchism', in Guttorm Fløistad (ed.), Contemporary Philosophy: A New Survey, Volume 12, Philosophy of Justice, 157-76. Dordrecht. (2015)

VICHINKESKI TEIXEIRA, A. 'Los orígenes filosóficos de la noción de soberanía nacional en el contractualismo político de Thomas Hobbes, John Locke y Jean-Jacques Rousseau' ('The Philosophical Origins of the Notion of National Sovereignity in the Political Contractualism of Thomas Hobbes, John Locke and Jean-Jacques Rousseau', Revista de derecho de la Pontificia Universidad Católica de Valparaiso 43 (2014), 801-19.

VIENNE, J-M. 'Education et empirisme: les apories de John Locke', Rassegna di pedagogia 72 (2014): 83-97.

VIENNE, J-M. 'Traduction et théorie du langage chez Locke', in Charles Le Blanc et Luisa Simonutti (eds.), Le masque de l'écriture: philosophie et truduction de la Renaissance aux Lumières, 611-625. Geneva. (2015)

VINCIGUERRA, L. 'Que signifient nos perceptions? Locke, l'anamorphose et le miroir', Methodos 16 (2016). Online, accessed 20 February 2017.

http://journals.openedition.org/methodos/4516

WADIWEL, D. J. 'The Will for Self-Preservation: Locke and Derrida on Dominion, Property and Animals', SubStance 43 (2014), 148-161.

WAKELY-MULRONEY, K. 'Isaac Watts and the Dimensions of Child Interiority', J. for Eighteenth-Century Studies 39 (2016): 103-19.

WALDMANN, F. 'Additions to De Beer's Correspondence of John Locke', Locke Studies 15 (2015): 31-52. 
WALDMANN, F. 'John Locke and a René Descartes Epitaph', Notes and Queries 62 (2015): 260-63.

WALDMANN, F. 'Locke, Horace, and a Syllabus errorum', Locke Studies 15 (2015): 3-29.

WALMSLEY, J. C. 'John Locke's "Anatomia" and "De arte medica": New Transcriptions. Drafted circa 1998-2005; posted March 25, 2014. Online, accessed 9 April 2017. https://medium.com/@craig_walmsley/john-lockes-anatomiaand-de-arte-medica-new-transcriptions-fe $368 \mathrm{fb} 5 \mathrm{c} 5 \mathrm{~b} 0$

WALMSLEY, J. C. 'The Later Development of Lockean Abstraction', Locke Studies 14 (2014): 59-84.

WALMSLEY, J. C. 'Locke, Ayers, and Abstraction', Locke Studies 14 (2014): 29-58.

WALMSLEY, J. C. 'Peter Anstey on Locke's Natural Philosophy', Locke Studies 16 (2016): 167-94. [Reply to Anstey 2015]

WALMSLEY, J. C., CRAIG, H, \& BURROWS, J. 'The Authorship of the Remarks upon an Essay Concerning Humane Understanding', Eighteenth-Century Thought 6 (2016): 20543.

WALSH, J. 'Locke and the Power to Suspend Desire', Locke Studies 14 (2014): 121-57.

WALSH, K. 'Locke and the Newtonian Achievement', Early Modern Experimental Philosophy. July 5, 2016. Online, accessed 8 July 2016.

https://blogs.otago.ac.nz/emxphi/2016/07/locke-and-thenewtonian-achievement/ 
*WANG, N. 劳动与财产: 约翰. 洛克思想研究. Labour and Property. 上海. / Lao dong yu cai chan: Yue hanLuo ke si xiang yan jiu. Labour and property. Shanghai. (2014)

WARD, L. 'James Otis and the Americanization of John Locke', Am. Pol. Thought 4 (2015): 181-202.

WEINBERG, S. Consciousness in Locke. Oxford. (2016)

WEINBERG, S. 'Locke on Knowing Our Own Ideas (and Ourselves)', Pacific Phil. Q. 97 (2016): 347-70.

WILSON, C. 'Managing Expectations: Locke on the Material Mind and Moral Mediocrity', Royal Institute of philosophy Supplement 78 (2016): 127-46.

WILSON, R. A. 'Primary and Secondary Qualities', in Stuart (ed.), A Companion to Locke, 193-211.

WILSON, R. A. 'Thinking about Relations: Strathern, Sahlins, and Locke on Anthropological Knowledge', Anthropological Theory 16 (2016): 327-49.

WILSON, T. D. The Ashley Cooper Plan: The Founding of Carolina and the Origins of Southern Political Culture. Chapel Hill, NC. (2016)

WINKLER, K. 'Locke on Essence and the Social Construction of Kinds', in Stuart (ed.), A Companion to Locke, 212-35.

WOOD, J. M. 'On Grounding Superadded Properties in Locke', Brit. J. Hist. Phil. 24 (2016): 878-96.

*WRIGHT, G. A. 'Hobbes, Locke, Darwin, and Zombies: The 
Post-Apocalyptic Politics of Survival in AMC's The Walking Dead', Q. Rev. of Film and Video 34 (2017): 148-70.

YACOUBA, C. 'Critique of John Locke['s] Objection to the Innate Ideas', Open J. of Phil. 6 (2016): 302-10.

YEO, R. Notebooks, English Virtuosi, and Early Modern Science. Chicago. (2014)

YEO, R. 'Notebooks, Recollection, and External Memory: Some Early Modern English Ideas and Practices', in Alberto Cevolini (ed.), Forgetting Machines: Knowledge Management Evolution in Early Modern Europe. (Library of the Written Word, volume 53), 128-54. Leiden. (2016)

ZANARDI, P. 'Echi settecenteschi del dibattito lockiano sull'sidentità personale', in Allegra (ed.), Perspectives on Locke: Monographica, Etica \& Politica. Ethics \& Politics 18/2 (2016), 181-95.

Pennsylvania State University (retired) 